\title{
INSTRUMENTS SPECIFIC TO THE PROCESS OF SUBSTANTIATING MANAGERIAL DECISIONS AT THE ORGANIZATION'S LEVEL
}

\author{
Mihalciuc Camelia Cătălina ${ }^{1}$ \\ Grosu Maria ${ }^{2}$
}

Received: June 20, 2019 / Revised: July 26, 2019/ Accepted: October 15, 2019

(C) Association of Economists and Managers of the Balkans, 2019

\begin{abstract}
The main objective of this paper is first to analyze those instruments that have proven to be useful in time and have the merit of being able to be used in the decision-making processes of all types of organizations such as the tree decision-making or decision table and on the other hand, another important aspect is the presentation of the organization's integrated piloting tools such as scoreboard and balanced scorecard, tools that allow managers to dispose, in real time, of a synthetic view of the main indicators of the organization and the business environment for taking decisions under their competence.
\end{abstract}

Keywords: Scoreboard, Balanced scorecard, Tree Decision-Making, Decision Table, Experiment and Decision-Making Simulation

JEL Classification L66 $\cdot$ M11 $\cdot$ M49

This paper was presented at the Fifth International Scientific Conference on Knowledge Based Sustainable Development - ERAZ 2019 - May 23, Budapest, Hungary, www.eraz.org.rs

Mihalciuc Camelia Cătălina

cameliam@seap.usv.ro

1 Faculty of Economics and Public Administration, University Stefan cel Mare Suceava, str. Universitatii, no. 13, Romania

2 Faculty of Economics and Business Administration, University A1. I. Cuza Iași, Bulevardul Carol I, nr. 22 Romania 


\section{INTRODUCTION}

The importance of using specific tools in the process of substantiating decisions within organizations stems from the necessity to adopt superior, clear and precise decisions, based complex, sometimes of great significance for organizations. Among the ways and instruments used to rationalize the entire decision-making process, specialized methods and techniques play a special role, being specially designed to increase the efficiency of decisions of great importance.

Organizational decision-making is the product of the managerial act, its purpose being dependent on the functionality, viability and performance of these organizations, with decision-making processes taking a major role in organizational activity (Berheci, 2008). The basis for the decision appears as a process of elaboration, in which the collection and processing of information, the study and selection of several alternatives and the formulation of the option for one of them occupy a central place in the activity of the organizations, the possibility of improving the decision making process depending primarily on its knowledge.

It is known that the decision-making process involves a great deal of time during which information is gathered and analyzed, people are consulted in order to shape the decisional situation, this process essentially consisting of a set of stages through which it prepares, adopts, applies and evaluates managerial decision, and its quality influences cost reduction, efficiency of fund utilization, profit growth, etc.

In top management practice, due to their simplicity, linear programming models used in the decision-optimization process allow for quick evaluation of the action lines and the identification of the optimal solution. Thus, in the approach of the applicative part, the authors considered a study conducted at a meat product organization called Alfa, which in 2018 decided to investigate the possibility of increasing the production capacities, and in order to solve this managerial complex problem with major financial implications will resort the use of the decision tree, a stochastic type instrument used to make decisions under risk and uncertainty. After applying this instrument, it can be seen from the examples of decisions taken by Alfa's management that the use of decision-making methods and techniques is all the more important as it provides an opportunity to adopt complex and substantiated decisions of high quality, resulting in an increase the degree of rigor and, implicitly, their effectiveness, differentiated according to the typology of the decisional situations involved. This advantage is doubled by the effort economy of the managers involved, due to pre-emptive decisional alternatives.

\section{IMPROVING THE DECISION PROCESS IN ORGANIZATIONS}

In the work of decision-makers from organizations, at this stage a relatively large number of decisions are based on the empirical or raw interpretation of the information that is circulating when drafting the decisional variants. The activity of optimizing of the relationships between the objectives pursued by the decision-maker and the existing resources needs to be approached sequentially, starting with the establishment of the production branches, the structure of the production processes and the obtained products and ending with their sale. The activity of improving the decision-making process is mainly carried out on three levels: organizational, informational and methodological. Managers develop and take many different decisions during their work, making managerial decisions synonymous with the entire management process (Popa, 2009, pp. 25-36). 
The decision in general is the conclusion of the process by which we make a choice, an option between two or more alternative actions available to achieve an objective or more, and the process of obtaining this conclusion or options, being known as the „decision-making process” (Ionescu, Cazan \& Negruţa, 1999)

Decision-making system consists of all decisions adopted and applied by managers within an organization. The decision can be defined as a deliberate choice from multiple possibilities in order to solve a problem (Trifu, 2009). Many organizations have market-oriented organizational structures, but few have specific decision-making systems for such organizations and, in particular, such guidelines (Baker, 2005).

Specialized literature, (Negescu, 2004, p. 54), faithfully reflecting on current practices in organizations, rather operates with a broad vision of decision-making, including in its post-election activities, such as: implementing and controlling the application of the decision.

Managerial process is understood, first of all, as a process of using information, (Paterson, 1996, p.12) the act of leadership being realized within the information-decision-action circuit, as can be seen in figure 1.

The complexity of the Simon's phases model, (Simon. 1977, p. 23) as well as some considerations about the importance of information in each of these phases - the decision being essentially a process of converting information into action - determines us to consider the development of this model, as it can seen in Figure 2.

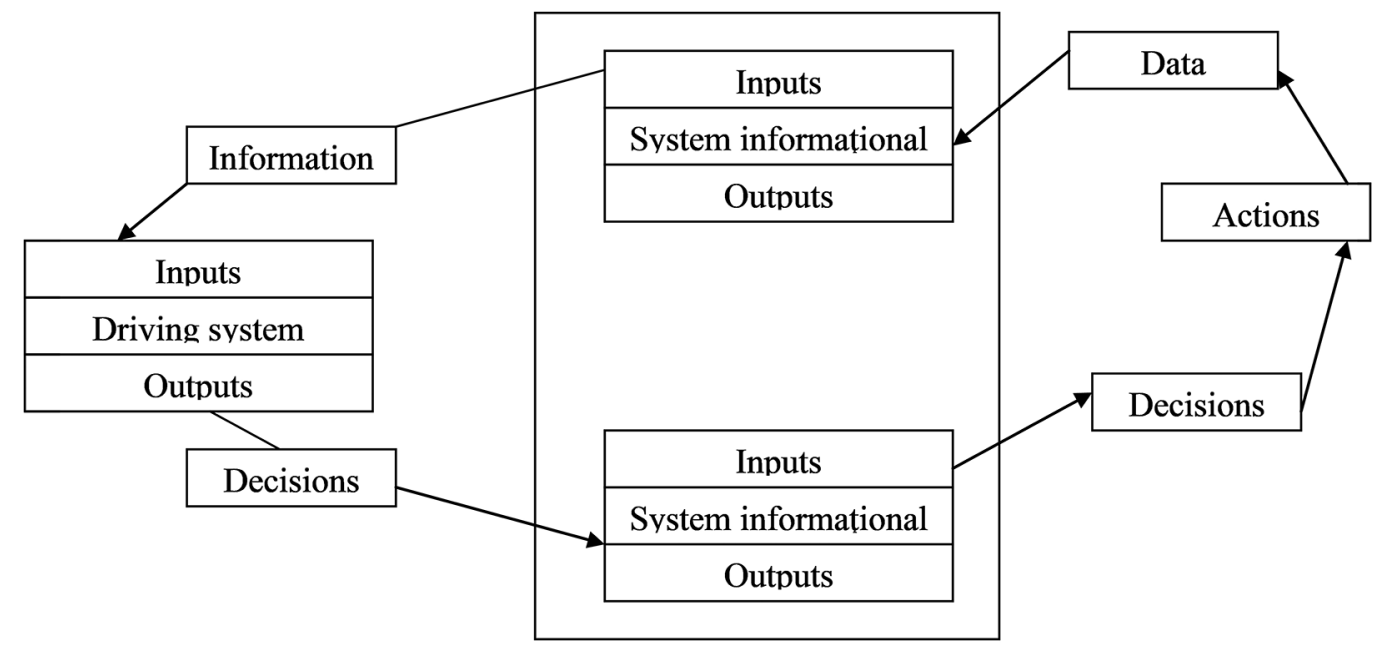

Figure 1. The link between the information system and the decision-making process Source: Paterson, 1996

The Sources of information origin used in decision-making are of two categories: formal and informal. Formal information is given to managers through the organization's official information systems, such as the types of computerized information systems developed - including database query facilities, decision support systems, information systems for senior management (Executive Information Systems), office applications and other facilities - can greatly satisfy these qualitative requirements. Managers prefer ,informal” information and use them to make decisions, especially when dealing with poorly structured, unscheduled problems (Mintzberg, 2008). 


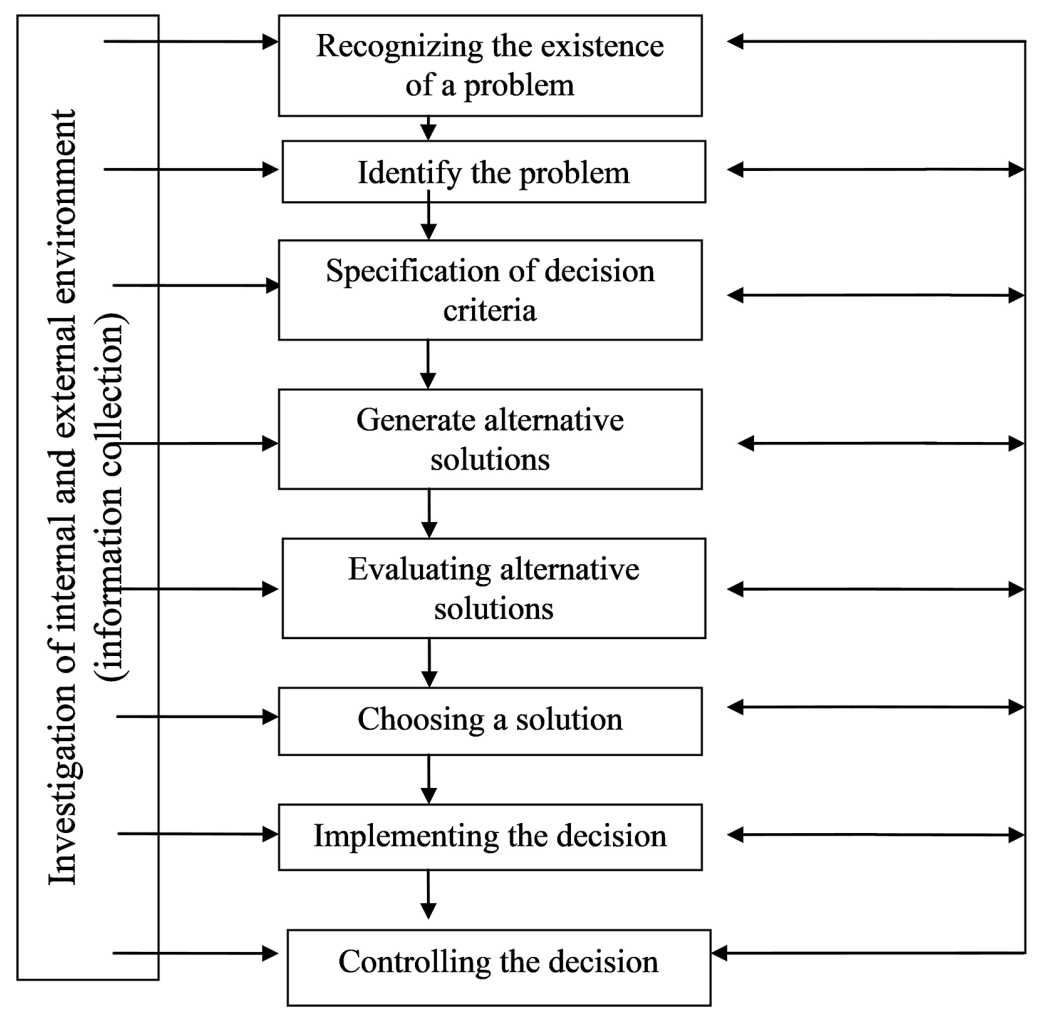

Figure 2. The structure of the effective decision-making process

Source: Simon, 1977

\section{THE IMPORTANCE OF USING SPECIFIC TOOLS IN THE PROCESS OF SUBSTANTIATING DECISIONS WITHIN ORGANIZATIONS}

The tools used to rationalize the entire decision-making process of all types of organizations are specifically designed to increase the efficiency of decisions of great importance, such tools being proven in time, such as decision tree, decision table, experiment and decision simulation, and as the organization's integrated piloting tools; the scoreboard and the balanced scorecard can be outlined.

In top management practice, due to their simplicity, linear programming models used in the decision-optimization process allow for quick evaluation of the action lines and the identification of the optimal solution. In linear decision-making models it is intended to optimize a problem by maximizing/minimizing the objective function (Ionescu, Cazan \& Negruţa, 1999), respecting a number of restrictions on the availability of resources or achieving binding targets.

The decision tree has as its main objective rationalizing the decision-making process, the "tree" being able to "attach" to any problem for which a decision is needed. The decision tree describes chronologically the various modes of action of the decision-maker, symbolized by squares and the "nature's reactions", random events, mostly symbolized by circles. Each pair of "action of the decision-maker - reaction of nature" determines an "r" result, the unique consequence of the said pair, symbolized by triangles (Filip, 2002). 
An alternative decision-making (decision-maker action) determines a result, expected or not, that depends on a random event (of a nature reaction) whose probability of occurrence can be anticipated, known in the probabilistic sense, following preliminary investigations. It follows that, to a great extent, the correctness of decisions made with the help of the "decision tree" is strictly dependent on (Bouquin, 2004, pp. 32-34):

1. the ability of the decision maker to identify the possible reactions of nature to its own action solutions, including through research tools. It is obvious that only the action-reaction pairs set by the manager will be studied.

2. the accuracy of the investigations necessary to anticipate the probabilities of occurrence of the various ,nature reactions" set by the decision maker, the methodology used for this purpose.

The decision table is a complex variant of the calculation nomograms and it is recommended to develop and use it in all cases where the manager is in a position to choose with a high frequency a decision from the same predefined alternatives in the ,table”. It usually presents four quadrants, in which are passed:

1. the objectives of the decision or the requirements to be taken into account when developing it;

2. the set of actions or operations required to achieve the possible objectives;

3. combinations of objectives and requirements as well as all the actions and operations required to achieve each combination of objectives or requirements (Radu, \& Vlădeanu, 2007).

Experimentation and simulation are two methods of research into economic phenomena that contribute significantly to increasing the quality of economic decisions, i.e. experimentation and decision simulation. The use of these two instruments enables decision makers to have a realistic and integral representation of the complexity of the interdependencies between the different factors of influence of the results (consequences) of the decisions to be made (Bărbulescu, 2000).

Nomograms are graphical representations in the plane using the gradient lines of the relationship of dependence between two or more variable sizes; serve to quickly determine, without calculations, the values of a size function of other sizes when given the values of the latter (Băileşteanu, 2002).

Decisional simulation ensures not only the rationalization of the decision-making process, but also, in this case, the possibility of anticipating all the consequences of the various decisions, in fact of the final decision (Mihalciuc, 2018). From this point of view, simulation is a unique tool, the use of decisional simulation for this purpose, offering the possibility of realizing a ,non-destructive” control of the effects of the decisions to be taken without the potential disastrous consequences of some major decisional errors (Radu \& Vlădeanu, 2007). Decisional simulation ensures not only rationalization, simulation of decision-making involves the prior construction of models that "simulate" the development of economic processes in the conditions that have been taken into account in the elaboration of the possible decisional variants to be applied. The most common types of simulations in the field of economic phenomena are based mainly on Monte Carlo and heuristic programming.

In recent years, tools are increasingly being used to allow managers to have a real-time vision of the main indicators of the organization and the business environment in order to make decisions within their competence, such as the picture board and balanced scorecard. The Scoreboard is a set of indicators that provide a readable and interpretable presentation with a regular frequency adapted to the needs of the pilot (Popa, 2005, pp. 32-46). 
The notion of a dashboard/,tableau de bord" appeared in France during the interwar period. A dashboard is a tool that has the ability to select, arrange, and present the indicators so that, at first glance, they can highlight a synthesis of the activity being carried out. As a pilot tool for managers' actions, the dashboard has the following features: it is intended for each operational manager; contains a relatively small number of indicators (10 to 25 maximum indicators); the information is not only of a financial nature, it also presents non-financial, qualitative indicators; is obtained quickly, being able to identify the origin of the information; is easy to understand and easy to interpret, and the indicators are presented in a visible manner, using graphs, tables, in absolute values and rates (Topor \& Marc, 2017, pp. 84-87).

The non-financial nature of some indicators is a specific feature for the scoreboard, which allows management to have data other than financial-accounting data. Non-financial information (for example, the quality level of the raw material, the percentage / degree of customer loyalty, the number of new clients, etc.) allows the decision-maker to react quickly when unexpected changes occur in the business environment is due to the fact that the operational officers are reporting qualitative rather than monetary data (Chiriţa \& Bradea, 2012).

Balanced Scorecard - the balanced development projection, a strategy-based model is a way of measuring and evaluating company performance, an Anglo-Saxon version of the dashboard. This tool is, as is already known, a management system (strategic) developed by Kaplan and Norton in the 1990s. If at first, the BS model was used to assess the (future) performance of companies (Kaplan \& Norton, 2001, pp. 87-104), then its application expanded beyond the business environment, being considered as a strategic planning tool for both public institutions and non-profit organizations. The Balanced Scorecard method was presented by Kaplan and Norton in the article "The Balanced Scorecard: Measures That Drive Performance" (BSC initially originated as a result of a KPMG-sponsored research project), being developed to ease managers' work through explaining the mission of the firm to which they belong, its purpose and strategy in a comprehensive set of performance measures that aim to achieve success on the competitive market (Mihăilă, Badicu, 2016)

The Balanced Scorecard is an approach that incorporates both traditional financial indicators or measures and non-financial indicators or measures. In essence, the BSC is primarily a mechanism for implementing the strategy and expressing the vision of the company. The BSC defines the most important success factors and the measures are designed in such a way as to support the completion of the enterprise objective and measure performance in vital areas from a strategic point of view (Bostan \& Grosu, 2011, p. 179). The essence of the model is that each field of analysis is assigned strategic objectives for which are set up measurement indicators and optimal levels, and then identify ways to implement the strategy.

In general, the process of implementing a strategy is a top-down process, and a well-designed BSC must reflect the strategy as a foundation for designing an efficient and effective management system. At the level of profit-making entities, financial perspective (shareholders /financiers), followed by customers (users), internal processes (activities), staff and innovation (adaptability and performance improvement) are the first. All this can be added to the perspective of creating value (De Geuser, Mooraj \& Oyon, 2009, pp. 93-122), (Aureli, Cardoni, Del Baldo \& Lombardi, 2018, pp. 191-215). Another point (Ștefănescu, Silivestru, 2012, pp. 6-23) is to place users first, second to second, staff and innovation to third, and fourth to the financial perspective. To all this, we can add value creation, an integrative perspective of the previous four (Aureli, Cardoni, Del Baldo \& Lombardi, 2018, pp. 191-215). 
Over time, the BSC method has expanded, applying the BSC Analytical Method (A-BSC) for various analyzes, such as: strategic performance analysis within an outsourced supply chain (De Felice, Petrillo \& Autorino, 2015). The BSC has been applied in various ways, with the Sustainability Balanced Scorecard (SBSC) approach being developed for SMEs (Falle, Rauter, Engert \& Baumgartner, 2016).

It is known that since its appearance in the early 1990s, many companies have adopted the Balanced Scorecard (BSC). In connection with this, some researchers have asked themselves: if BSC adds value to companies and if so, how does it contribute to organizational performance? The results indicated that Balanced Scorecard has a positive impact on organizational performance, improving the integration of management processes (De Geuser, Mooraj \& Oyon, 2009, pp. 93-122).

In the BSC, as a tool for implementing the strategy in an organization, attention is directed mainly to non-financial indicators that track the satisfaction of the individual, whether client or employee, the duration of the processes, the quality of the results, but also other aspects (Mihalciuc, Costaş \& Barnea, (2017). Although researchers have been analyzing the impact of BSC implementation on managerial and organizational performance over the years, however, at the level of 2010, there was little empirical evidence available to justify the BSC's large-scale efficiency (Burkert, Davila \& Oyon, 2010, pp. 345-363)

Regarding the use of BSC in areas other than those of companies, it is noted that in $2010,65 \%$ of Swedish emergency hospitals used the BSC method to implement their strategies. However, it is recommended to develop the BSC in order to be relevant in monitoring performance in the medical field (Aidemark, Baraldi, Funck \& Jansson, 2010, pp. 363 - 385).

There are also studies showing that among the factors that influence the school dropout rate are the limited financial resources of the students, the top and the size of the universities, as well as the qualitative characteristics of a university. It has been historically and statistically proven that there is a very positive correlation between higher quality education and economic growth (Kim \& Kim, 2018, pp. 954-972).

The implementation of BSC in an organization is in fact identifying itself with the definition, management, and control of that organization's strategy. The strategy targets long-term goals, and their achievement requires decision-making. In this context, the BSC model cell is a system of indicators (predictive, not static) that underpin decision-making (Albu \& Albu, 2003)

\section{APPLICATION OF THE DECISION-MAKING INSTRUMENTS TO SC ALFA}

SC ALFA is a meat processing company, Romanian legal person, the company's status is limited, the company owning an ecological type IE incinerator designed to destroy a category of hazardous wastes (waste from the meat processing industry, waste resulting from the practice human and veterinary medical, as well as some pharmaceutical waste), with no emission potential in the emission and, implicitly, noxious metals in the ashes. During its existence, S.C. ALFA, as any organization, has faced numerous disturbing factors, generated by the increasing business complexity and the environment of their deployment, which has resulted in a permanent concern for the expansion of activity and alignment with market standards. Thus, in 2018, the company decides to investigate the possibility of increasing production capacities, making it possible to take into account three options: a large factory can be built, a small factory can be constructed or not built. The market may be favorable or unfavorable with a probability that the manager can determine. 
To solve this complex management problem, with major financial implications, the decision tree is used, a stochastic type instrument used for risk and uncertainty decision making.

As a scientific decision-making technique, the decision-making process will go through a set of steps (Popa, 2009, pp. 25-36), (Ionescu, Cazan \& Negruţa, 1999), (Radu \& Vlădeanu, 2007) through which the decision-making process is prepared, adopted, applied and evaluated, especially since the quality of the decision-making process influence the efficiency of fund usage, reduce costs, increase profit, etc.

Step 1: In the first stage, the objective of the company was established and the possible alternatives were determined, namely: increasing the production capacity, taking into account the alternatives: a - construction of a large factory; $b$ - construction of a small factory; $\mathrm{c}-$ it is not being built.

Step 2: The decision tree of the stated problem (figure 3) is constructed in such a way that all the decisional alternatives and all the states of nature are represented, in a stepwise, logical order.

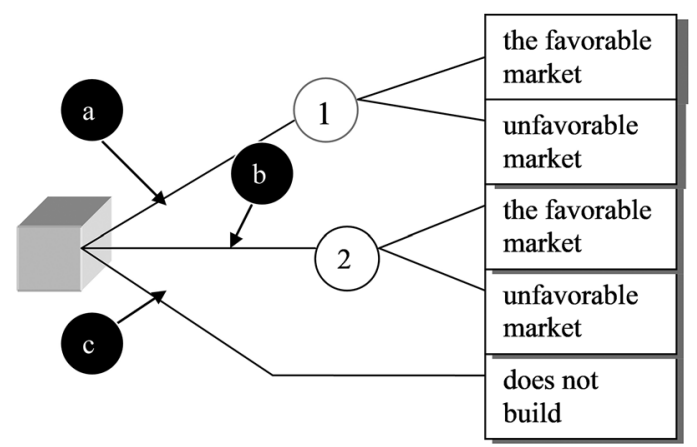

Figure 3. The decision tree for possibilities of SC ALFA

Step 3. Determine the level of consequences associated with each alternative.

Determining the values of the consequences for each alternative can be a synthetic and suggestive decision table (Table 1).

Table 1. Decisional table

\begin{tabular}{|l|c|c|}
\hline \multicolumn{3}{|c|}{ Consequences of alternatives } \\
\hline \multirow{2}{*}{ ALTERNATIVES } & \multicolumn{2}{|c|}{ STATES OF NATURE } \\
\cline { 2 - 3 } & FAVORABLE & UNFAVORABLE \\
\hline Very large construction & 400.000 u.m. & -360.000 u.m. \\
\hline Very small construction & 200.000 u.m. & -40.000 u.m. \\
\hline No construction & 0 & 0 \\
\hline
\end{tabular}

Were, u.m. represents monetary units

Step 4. Determining event probabilities

If we do not know the probability that characterizes the states of nature, we have a decision-making problem in case of uncertainty, which can be solved on the basis of specific game theory criteria: maximax, maximin and the probability average (equal probability for both alternatives). So: 
1. if we choose the maximax criterion, which means maximizing winnings - a large factory is being built, which in case of success will bring a gain of 400,000 u.m.;

2. if we choose the maximin criterion, which means minimizing the losses - it is not built, the loss in this case being 0 ;

3. if we choose the probability average criterion, which implies the determination of the average of the consequences for each alternative:

1.1. for large factory construction, the gain is $(400.000-360.000): 2=20.000$;

1.2. for the small factory construction, the gain is $(200.000-40.000): 2=80.000$;

1.3. for the variant that: not build, the gain is 0 .

As you can see, it will be decided to build a small factory that corresponds to a higher average gain. The risk decision is a probabilistic decision, the states of nature being appreciated by certain probabilities. Under these conditions, the conditional values in the decision table are weighted with the likelihood of each state of nature occurring and the expected monetary value (EMV) for each alternative is determined. For the situation of the company, the market can be manifested in two ways based on the following determined probabilities: favorable market - 0,6 and unfavorable market - 0,4.

Step 5: Calculation of the mathematical expectation for each decisional alternative, stage in which the expected values are estimated for each possible combination of alternatives and the states of nature. According to the above presented for each alternative we have:

$$
\begin{aligned}
& \mathrm{EMV}_{1}=400.000 \times 0,6-360.000 \times 0,4=240.000-152.000=88.000 \text { u.m. } \\
& \mathrm{EMV}_{2}=200.000 \times 0,6+(-40.000) \times 0,4=120.000-16.000=104.000 \text { u.m. } \\
& \mathrm{EMV}_{3}=0 \times 0,6+0 \times 0,4=0
\end{aligned}
$$

Step 6: Choosing the decision variant based on the maximum value obtained.

So, based on the results obtained, the second alternative will be chosen, which will ensure a higher monetary value.

\subsection{The decision tree under total information}

However, society does not agree with the situations generated by the acceptance of probabilities and aims to carry out research, so that the uncertainties will be completely eliminated, and the decision will be accurate and scientifically substantiated. Under such circumstances, knowing the value of the final result with certainty, the decision-maker must be able to properly assess the states of nature on the basis of information that will remove the problem from the risk conditions and turn it into a determined problem. So, we will have to determine the cost to get complete information.

Noting with: EMI - the expected monetary value for full information EMC - the monetary value expected in certainty conditions

We have:

$$
\mathrm{EMI}=\mathrm{EMC}-\mathrm{MAX}(\mathrm{EMV})
$$


In which: EMC is the value of the most favorable alternative $\mathrm{x}$ the probability of that alternative + the most unfavorable alternative $\mathrm{x}$ the probability of that alternative.

In our case:

$$
\mathrm{EMC}=400.000 \times 0,6+0 \times 0,6=240.000 \text { u.m. }
$$

It results:

$$
\mathrm{EMI}=240.000-104.000=136.000 \text { u.m. }
$$

So, to transfer the managerial problem from the risk category into a certainty, information that will cost 136,000 u.m should be collected. Prior to building the factory, the manager decided to develop a marketing study costing 10,000 u.m. The study shows that there is a $45 \%$ probability of the development outcome being favorable and 55\% unfavorable. In the case of favorable research, the chances of the market being favorable rise to $78 \%$, and only $27 \%$ of the market would be favorable for the unfavorable study. If it is not built, the likelihood of the market behaving favorably or unfavorably is considered to be $50 \%$.

The decision tree shown in Figure 4 changes radically, but the three options remain
1. a - we build a large factory;
2. $\quad \mathrm{b}$ - we are building a small factory;
3. $\quad \mathrm{c}-$ we do not build.

Applying the abbreviated formulas, we determine the expected monetary values for each decision node.

$$
\begin{aligned}
& \operatorname{EMV}(2)=390.000 \times 0,78+0,22 \times(-370.000)=222.800 \text { u.m. } \\
& \operatorname{EMV}(3)=190.000 \times 0,78+0,22 \times(-50.000)=137.200 \text { u.m. }
\end{aligned}
$$

For decision node B, the maximum EMV is 222,800 u.m., a large factory is being built.

$$
\begin{aligned}
& \operatorname{EMV}(4)=390.000 \times 0,27+0,73 \times(-190.000)=-164.800 \text { u.m. } \\
& \operatorname{EMV}(5)=190.000 \times 0,27+0,73 \times(-30.000)=14.800 \text { u.m. }
\end{aligned}
$$

For decision node $\mathrm{C}$, the maximum EMV is 14,800 u.m., a small factory is built.

$$
\begin{aligned}
& \operatorname{EMV}(6)=400.000 \times 0,50+0,50 \times(-360.000)=20.000 \text { u.m. } \\
& \operatorname{EMV}(7)=200.000 \times 0,50+0,50 \times(-40.000)=80.000 \text { u.m. }
\end{aligned}
$$

For decision node D, the maximum EMV is 80,000 u.m., a small factory is built. If the study is favorable or not, there is an EMV according to the calculations:

$$
\operatorname{EMV}(1)=222.800 \times 0,45+0,55 \times 14.800=108.400 \text { u.m. }
$$

For decision node A, the maximum EMV is 108.400 u.m., so the study is being developed. 
The decisional stages in the managerial problem are:

1. the study is being developed;

2. if the study is favorable, a large factory is built;

3. if the study is not favorable, a small factory is being built.

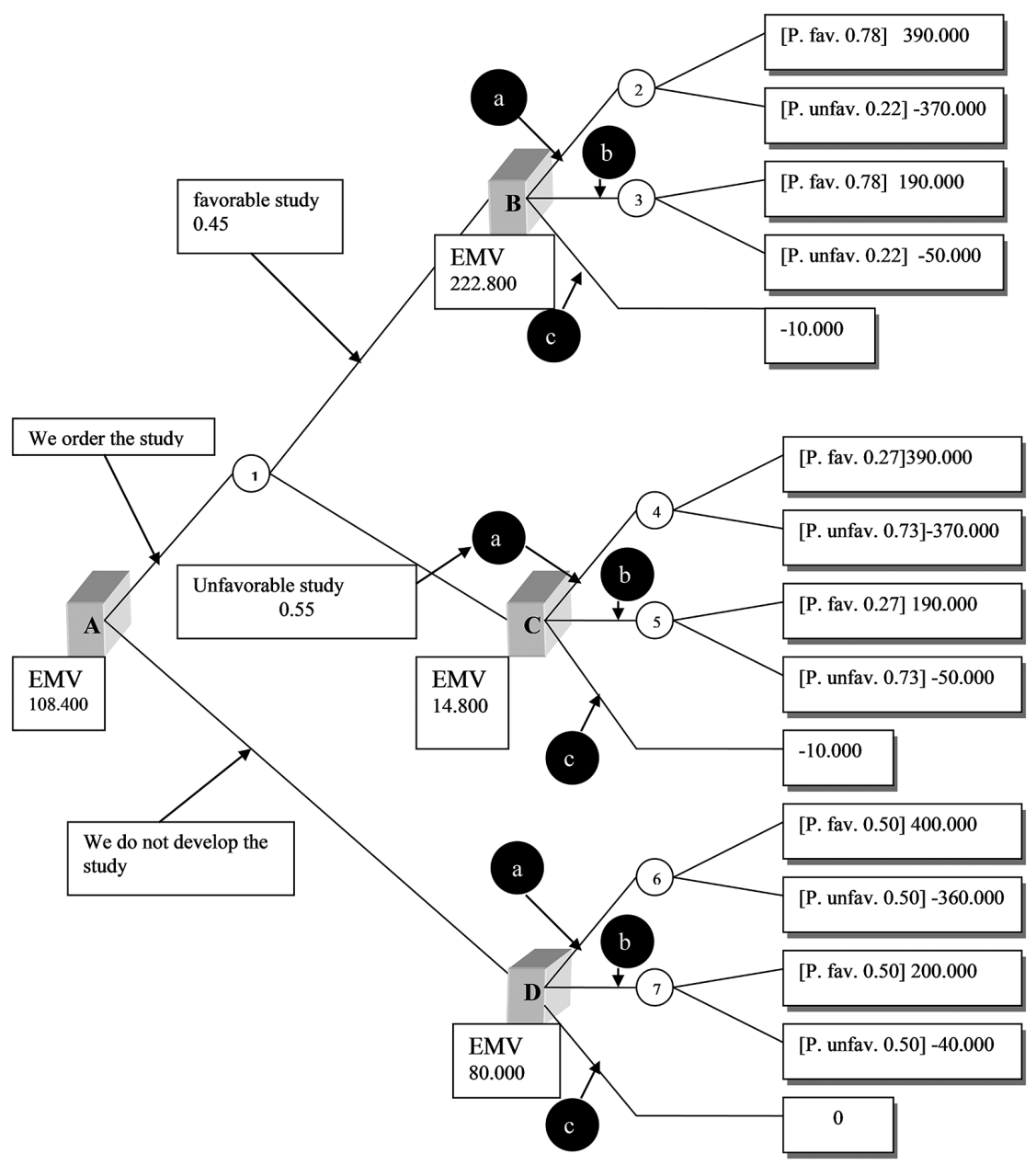

Figure 4. The decision tree for the issue of development SC ALFA

Another decision by S.C. ALFA was taken over the purchase of a new production line that will have to be installed in its factory. For equipment endowment, the company had to choose one of the following three alternatives as it can be seen in Figure 5:

1. To buy a machine that can perform several operations, so it can be used for general purposes, which in case of success will lead to a gain of 37,000 u.m., and in case of failure to a loss of 19,000 u.m.

2. Buy a strictly specialized equipment that will lead to a 43,000 u.m gain. in case of success and at 30,000 u.m. loss in case of failure.

3. If no machine is purchased from S.C. ALFA will have a loss of 13,000 u.m. due to the lack of space and customer dissatisfaction with non-assimilated products.

SC ALFA has calculated a 70\% success rate for each purchased equipment. 


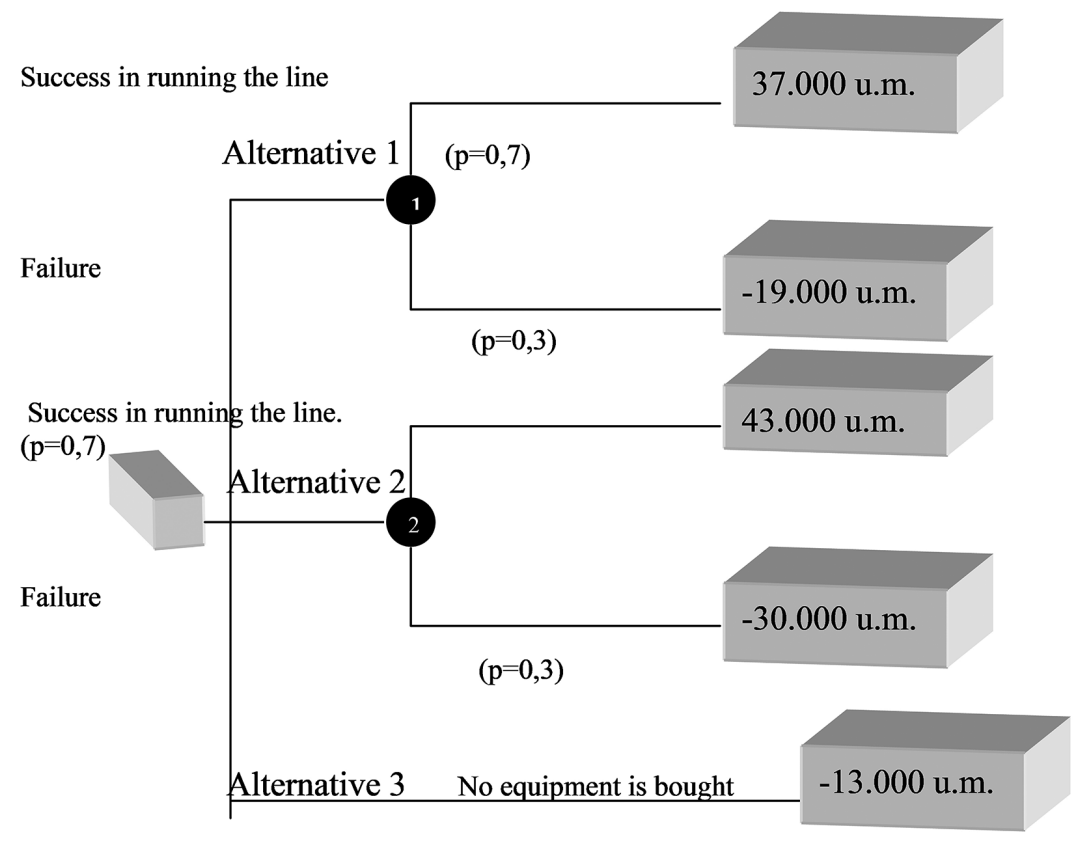

Figure 5. Decision tree for the problem of purchasing equipment at S.C ALFA

The expected monetary value of EMV for alternative 1, i.e. the purchase of a multi-purpose machine, can be calculated as follows:

$$
\operatorname{EMV}(1)=0,7 \times 37.000+0,3 \times(-19.000)=20.200 \text { u.m. }
$$

For alternative 2, the expected money is:

$$
\operatorname{EMV}(2)=0,7 \times 43.000+0,3 \times(-30.000)=21.100 \text { u.m. }
$$

Not buying any equipment results with certainty (probability $=1$ ), a loss of 13,000 u.m.

In conclusion, with no additional information (relating to the use of the universal machine for other purposes), the company will choose the variant 2, namely the purchase of a specialized equipment, because according to decision making using the decision tree, this alternative has the highest expected monetary value $(\mathrm{EMV}=21.100 \mu \mathrm{m})$. Another situation where it is necessary to make a well-thoughtout and considered decision before it is put into practice, as it influences the costs, the efficiency of using the funds, the profit, would be the following: In order to manufacture an assortment for a defined period, a single device with a unit purchase cost (CA) of 30 u.m. is mounted on the three existing machines. $\mathrm{m}$, whose reliability is low. The company has two options: it can be supplied early with one or more devices (action lines V; where $\mathrm{j}-1,2,3$ ) or can purchase them at the time of failure (Vo). In this latter situation, costs due to stagnation of production up to the arrival of a device (CS) are $40 \mathrm{u} . \mathrm{m}$.

On the basis of reliability studies, probability distribution $\mathrm{P}(\mathrm{k})$, where $\mathrm{p}(\mathrm{k})$ is the probability of simultaneously defecting „,k” devices, was estimated.

$$
P(K)=(0,100,350,400,15)
$$


The company has action lines $\mathrm{V}$, with each variant being able to take the state of nature Nk. Following the choice of the line of action that involves a minimal hoped cost, the decision tree represented in Figure 6 can be elaborated.

Total costs (CT), related to each incidence of "action line - status of nature", were determined by summing up the acquisition costs (CA) and those due to production stagnation (CS), according to the relationship:

$$
\mathrm{CT}_{\mathrm{ij}}=\mathrm{CA} \cdot \mathrm{j}+\left\{\begin{array}{l}
(\mathrm{CA}+\mathrm{CS}) \cdot(\mathrm{i}-\mathrm{j}), \text { if } \mathrm{i}>\mathrm{j}_{1} \\
0, \text { for } i \leq j
\end{array}\right.
$$

where:

$\mathrm{i}$ - the number of defective devices in the considered period;

$\mathrm{j}$ - number of devices in stock.

We calculate the expected cost of total costs:

- for action line $\mathrm{V}_{0}$ :

$$
\mathrm{CT}=0,10 \times 0+0,35 \times 70+0,40 \times 140+0,15 \times 210=112
$$

- for action line V1:

$$
\mathrm{CT}=30 \times 0,10+30 \times 0,35+100 \times 0,40+170 \times 0,15=79
$$

- for action line V2:

$$
\mathrm{CT}=60 \times 0,10+60 \times 0,35+60 \times 0,40+130 \times 0,15=70,5
$$

- for action line V3:

$$
\mathrm{CT}=90 \times 0,10+90 \times 0,35+90 \times 0,40+90 \times 0,15=90
$$

In conclusion, following the calculations, it results that the optimal action line is V2, namely the constitution of a stock of two devices.

SC ALFA was confronted in September 2018 with the following one-time decision: three maintenance engineers $(\mathrm{X}, \mathrm{Y}, \mathrm{Z})$ must be assigned to repair three equipment $(\mathrm{A}, \mathrm{B}$ and $\mathrm{C})$ so that the repair time is minimum (Table 2 ).

Table 2. The time of equipment repair

\begin{tabular}{|c|c|c|c|}
\hline Equipment Mechanic & A & B & C \\
\hline$X$ & 6 & 14 & 8 \\
\hline$Y$ & 8 & 14 & 12 \\
\hline$Z$ & 8 & 16 & 12 \\
\hline
\end{tabular}

Based on the table, you can build a table of results corresponding to all possible alternatives (Table 3). 
Table 3. The table of results

\begin{tabular}{|c|l|}
\hline Alternatives & $\begin{array}{c}\text { The table of results } \\
\text { (total repair time) }\end{array}$ \\
\hline $\mathrm{A} 1-\mathrm{X}-\mathrm{A}, \mathrm{Y}-\mathrm{B}, \mathrm{Z}-\mathrm{C}$ & $6+14+12=32$ \\
\hline $\mathrm{A} 2-\mathrm{X}-\mathrm{A}, \mathrm{Y}-\mathrm{C}, \mathrm{Z}-\mathrm{B}$ & $6+12+16=34$ \\
\hline $\mathrm{A} 3-\mathrm{X}-\mathrm{B}, \mathrm{Y}-\mathrm{A}, \mathrm{Z}-\mathrm{C}$ & $14+8+12=34$ \\
\hline $\mathrm{A} 4-\mathrm{X}-\mathrm{B}, \mathrm{Y}-\mathrm{C}, \mathrm{Z}-\mathrm{A}$ & $14+12+8=34$ \\
\hline $\mathrm{A} 5-\mathrm{X}-\mathrm{C}, \mathrm{Y}-\mathrm{B}, \mathrm{Z}-\mathrm{A}$ & $8+14+8=30$ \\
\hline $\mathrm{A} 6-\mathrm{X}-\mathrm{C}, \mathrm{Y}-\mathrm{A}, \mathrm{Z}-\mathrm{B}$ & $8+8+16=32$ \\
\hline
\end{tabular}

By comparing the total repair time for all possibilities, it is concluded that the best alternative is A5 because the repair time is minimal (the objective function is to reach the minimum). As can be seen from the examples of decisions adopted by the management of SC ALFA, the use of decision-making methods and techniques is all the more important as it provides an opportunity to adopt complex and substantiated decisions of high quality, leading to an increase in the degree of rigor and, implicitly, their effectiveness, differentiated according to the typology of the decision situations involved. This advantage is doubled by the effort economy of the managers involved, thanks to the pre-decision-making alternatives.

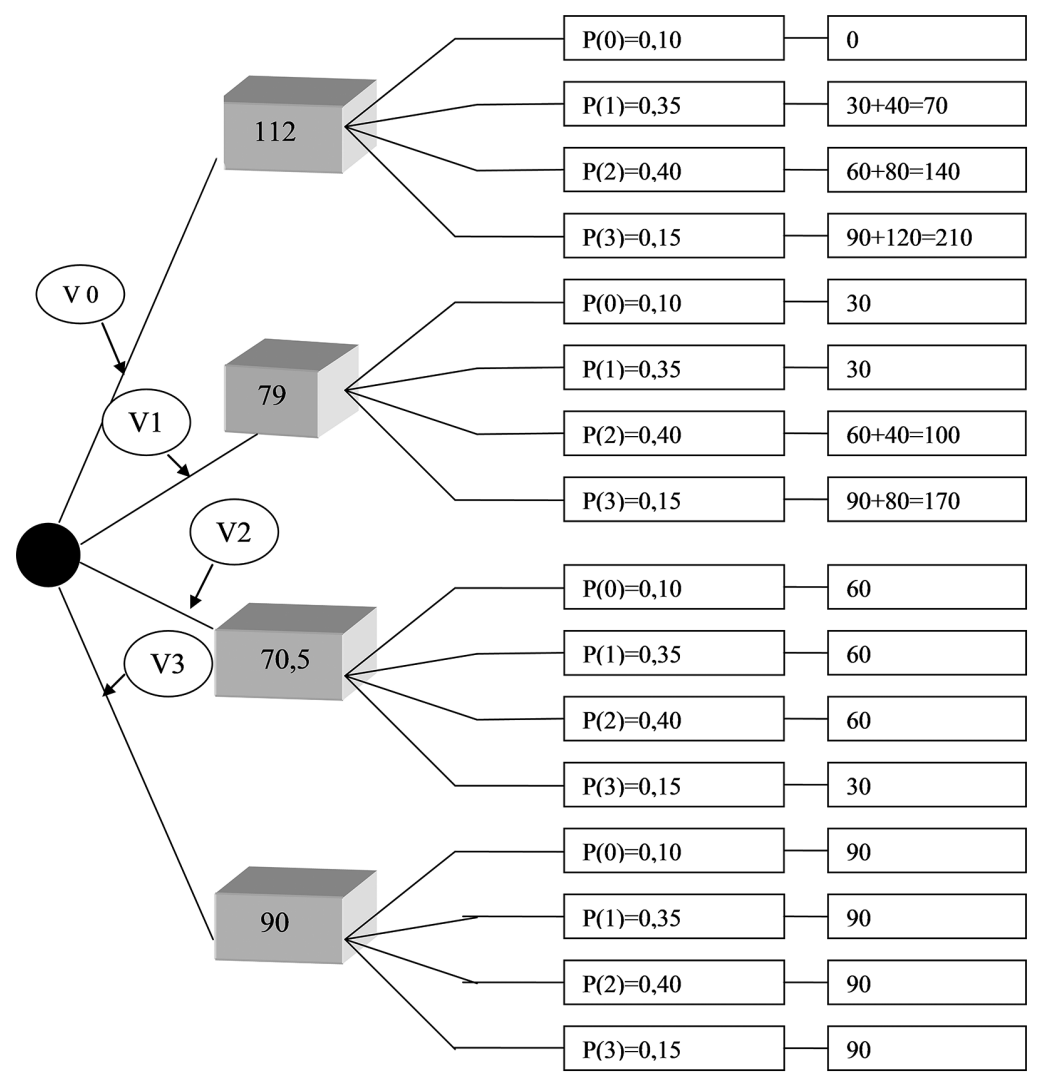

Figure 6. Decisional tree for the problem of acquiring devices at S.C. ALFA 


\section{CONCLUSION}

Decision-making techniques have generally developed as a result of the need for good decisions, with each manager having a set of tools (techniques / methods) that assist him / her in the decision-making process, dynamic character, with a complex problem, whose solution requires a great deal of discretion, clear delineation of the objectives and conditions, the courage to give up what is overcome and the use of the opportunities offered by information technology, which has become a highly competitive weapon in achieving the organization's goals.

\section{REFERENCES}

Aidemark, L. G., Baraldi, S., Funck, E. K., \& Jansson, A. (2010). The importance of balanced scorecards in hospitals. In M.J. Epstein, J.F. Manzoni, \& A. Davila (Eds.), Performance Measurement and Management Control: Innovative Concepts and Practices (pp. 363 - 385), Studies in Managerial and Financial Accounting, Volume 20, Emerald Group Publishing Limited, Howard House.

Albu N., \& Albu C. (2003). Instrumente de management al performanţei, vol. II, Control de gestiune, Bucureşti, Romania: Editura Tribuna Economică.

Aureli, S., Cardoni, A., Del Baldo, M., \& Lombardi, R. (2018). The balanced scorecard logic in the management control and reporting of small business company networks: A case study, Accounting and Management Information Systems, 17(2), 191-215. https://doi.org/10.24818/ jamis 2018.02001

Băileşteanu, G. (2002). Logică economică, Timişoara, Romania: Editura Mirton.

Baker, M. J. (2005). Marketing, Bucureşti, Romania: Editura Ştiinţă şi Tehnică.

Bărbulescu, C. (2000). Pilotajul performant al întreprinderii, Bucureşti, Romania: Editura Economică.

Berheci, M. (2008). The Annual Reports And Financial Decisions, Annales Universitatis Apulensis Series Oeconomica, Faculty of Sciences, „1 Decembrie 1918” University, Romania, Alba Iulia, vol. 1(10), 1-17.

Bostan, I, \& Grosu, V. (2011). Contribution of balance scorecard model in efficiency of managerial control, Romanian Journal of Economic Forecasting, Institute for Economic Forecasting, vol. 0(3), pp. 178-199.

Bouquin, H. (2004). Contabilitate de gestiune, traducere Tabără, N., Iași, Romania: Ed. Tipo Moldova.

Burkert, M., Davila, A., \& Oyon, D. (2010). Performance consequences of balanced scorecard adoptions: claim for large-scale evidence and propositions for future research. In M.J. Epstein, J.F. Manzoni, \& A. Davila (Eds.), Performance Measurement and Management Control: Innovative Concepts and Practices (pp. 345 - 363), Studies in Managerial and Financial Accounting, Volume 20, Emerald Group Publishing Limited, Howard House.

Chiriţa, N., \& Bradea, I. A. (2012). Using Computer for Enterprise Risk Management, A şaptea ediție a Conferinței Internaționale de Analiză de Cibernetică Economică - The New Economic Crisis: Evolution and Recovering Ways - NEC2012, Editura ASE, București.

De Felice, F., Petrillo, A., \& Autorino, C. (2015). Development of a Framework for Sustainable Outsourcing: Analytic Balanced Scorecard Method (A-BSC), Sustainability, 7, 8399-8419. https://doi.org/10.3390/su7078399

De Geuser, F., Mooraj, S., \& Oyon, D. (2009). Does the Balanced Scorecard Add Value? Empirical Evidence on its Effect on Performance, European Accounting Review, 18(1), 93-122. https:// doi.org/10.1080/09638180802481698 
Falle, S., Rauter, R., Engert, S., \& Baumgartner, R. J. (2016). Sustainability Management with the Sustainability Balanced Scorecard in SMEs: Findings from an Austrian Case Study, Sustainability, 8, 545-561. https://doi.org/10.3390/su8060545

Filip, F.G. (2002). Decizie asistată de calculator: decizii, decidenţi, metode şi instrumente de bază, Bucureşti, Romania: Editura Expert şi EdituraTehnică.

Ionescu, G., Cazan, E., \& Negruţa, A. L. (1999). Modelarea şi optimizarea deciziilor manageriale, Cluj-Napoca, Romania: Editura Dacia.

Kaplan, R. S., \& Norton, D. P. (1996). The balanced scorecard: Translating strategy into action. Boston: Harvard Business School Press. In Kaplan, R.S.; Norton, D.P. (2001) Transforming the balanced scorecard from performance measurement to strategic management: Part I. Accounting Horizons, 15(1), 87-104.

Kim, D., \& Kim, S. (2018). Sustainable Education: Analyzing the Determinants of University Student Dropout by Nonlinear Panel Data Models, Sustainability 10, 954-972. https://oi. org/10.3390/su10040954

Mihăilă, S., \& Badicu, G. (2016). Informaţia contabilităţii de gestiune - sursă fundamentala în analiza performanţei dezvoltării durabile a entităţilor. In Paradigm of accounting and auditing: national realities, regional and international trends, Communications of the International Scientific Conference, 5th Edition dedicated to the Professional Accountant's day, April 2016, Chisinau, Republic of Moldova.

Mihalciuc, C., Costaș, R., \& Barnea L., (2017). Concepții referitoare la managementul și măsurarea performanței firmei, Conferința Științifică Internaținală Paradigme finaciar-contabile în viziunea tinerilor cercetători, (pp. 119-124), Chișinău.

Mihalciuc, C., (2018), Tools designed to analyse the enterprise economic risk and its usefulness for forecasting and managerial control. In C., Nastase (Ed.) book: Strategies and development policies of territories. International, country region, city location challenges, Lumen Procedings, vol. 6, (pp. 361-374), no. 1,Romania, Iași.

Mintzberg, H. (2008). Ascensiunea şi declinul planificării strategice, Bucureşti, Romania: Editura Publica.

Negescu, M.D., (2004). Informaţia financiară - suport în luarea deciziilor, Revista Contabilitate şi informatică de gestiune nr. 9/2004, Editura ASE, Bucureşti.

Paterson, T. T. (1996). Management Theory, London, UK.

Popa, I.A. (2009). Sisteme de asistare a deciziilor adaptate în organizaţii, Editura Economică, București.

Popa, V., (2005). Managementul și măsurarea performanței organizației, Târgul Mureș, Romania: Editura Valahia University Press.

Radu, I., \& Vlădeanu, D. (2007). Fundamentarea deciziilor complexe din tehnici desimulare, Bucureşti, Romania, Editura Economică.

Simon, N. A. (1977). The new science of Management Decision, Ed. Rev. Englewood Cliffs NJ Prentice Hall.

Ştefănescu, D., \& Silivestru, M. (2012). Balanced Scorecard - instrument de planificare strategică, Romanian Statistical Review 2, 6-23.

Ştefănescu, D., Silivestru, M., Topor, I. D., \& Marc, M. A. (2017). Măsurarea performanței în contextual aplicării standardelor internaționale de raportare financiară. In Paradigme finaciar-contabile în viziunea tinerilor cercetători, Conferința Științifică Internaţinală Paradigme finaciar-contabile în viziunea tinerilor cercetători, (pp. 84-87), Chișinău.

Trifu, A. (2009). Universul multidimensional al deciziei, Bucureşti, Romania: Editura Economică. 